\title{
Corporate Social Responsibility (CSR) in Pakistan: A Critique of the Literature and Future Research Agenda
}

\begin{abstract}
Mohammad Sohail Yunis ${ }^{1}$, Laila Durrani ${ }^{2}$, Amad Khan $^{3}$
Abstract

This paper critically captures an up-to-date picture of the empirical and theoretical contributions regarding CSR literature in Pakistan. This paper has systematically assessed the thematic and chronological contributions which include various methodological tools and suggested future research avenues in the context of Pakistan. The review indicates that companies often practice CSR as a short term, reactive tool based on philanthropic activities in the context of Pakistan. Moreover, the focus of most of CSR researches in Pakistan is towards child labour issues and leather and textile industry. Based on review of the literature, we establish that the currently popular methodological approach among researchers is either a micro-level case study approach or a macro-level exploratory approach. It is concluded, therefore, that the limited number of researches in Pakistan on CSR provides opportunity for further research in different theoretical perspectives and sectors. In addition to this, the scope of CSR in Pakistan can be extended towards a wide range of CSR issues including environment, stakeholders and corporate social disclosure. Moreover, it is suggested that more predictive, pragmatic and empirical research methodologies should be adopted in future.
\end{abstract}

Keywords: Corporate social responsibility, CSR, child labor, Pakistan, developing countries

\section{Introduction}

Review of contemporary literature suggests that corporate social responsibility (CSR) is a highly contested domain amidst both practitioners and academicians. Recently, CSR has emerged as a vital concept with political, social, and economic dimensions in both developing and developed countries (Carroll, 1999; Jamali \& Karam,

1 Assistant Professor, Institute of Management Sciences, Peshawar. Email: sohail.younis@imsciences. edu.pk

2 Research Scholar, Institute of Management Sciences, Peshawar.

3 Research Scholar, Institute of Management Sciences, Peshawar.

\begin{tabular}{llll}
\hline \multicolumn{2}{l}{ ARTICLE HISTORY } & & \\
25 Oct, 16 & Submission Received & 31 Oct, 16 & First Review \\
\hline 15 Nov, 16 & Revised Version Received & 28 Nov, 16 & Second Review \\
\hline 28 Dec, 16 & Revised Version Received & 10 Jan, 17 & Accepted
\end{tabular}


2016; Matten \& Crane, 2005). The relevance of CSR research is being recognized in this globalized world. Owing to the globalizing trends and enormous opportunities, it also forms a distinct line between the haves and the have nots. Consequently, globalization has led to insurmountable perils such as unemployment, famine, drought, human rights violations, flawed education, environmental pollution, and poverty (Rischard, 2002; Schrecker, 2014; Zadek, 2001). Henceforth, as the economic dimensions are liberating and political branches are transforming globally, innovation and new ideas are manifested, and therefore, the elaborative debate on CSR has generated numerous philosophies through academic literature (Geva, 2008). It has been argued in the literature that numerous political and economic issues are interwoven strongly with emerging economies of Asia, Latin America, and Africa as compared to that of the industrialized developed nations (Kratou \& Goaied, 2016; Rischard, 2002). This global divide between the developed and developing countries is due to the gap in technical, power, trained labor force, and effective management of social and national organizations. In addition, role of business in the developing countries is yet to be discovered and understanding of CSR initiatives is scant (Blowfield \& Frynas, 2005; Lund-Thomsen, Lindgreen, \& Vanhamme, 2014).

Pakistan is no exception to the aforementioned context of developing countries. Perhaps, Pakistan became acquainted with CSR for the first time when issue of child labor in the football industry (Sialkot, Pakistan) hit the international headlines (Winstanley, Clark, \& Leeson, 2002; Awan, Kamal, Rafique, \& Khan, 2012). This epidemic issue gave rise to the emergence of national and international non-governmental organizations (NGOs), specifically those NGOs which were working towards the awareness of CSR (Securities Exchange Commission of Pakistan [SECP], 2005). Nevertheless, academic literature related to CSR in Pakistan is scarce despite the fact that different organizations such as Pakistan Centre for Philanthropy (PCP), United Nations Industrial Development Organization (UNIDO), United Nations Development Program (UNDP), International Labor Organization (ILO), and Responsible Business Initiative (RBI) are engulfed in CSR dynamics and in a relationship with the community.

Academicians and practitioners have been concerned regarding the role of business in society for a long time (Kell, 2016; Scherer \& Palazzo, 2011; Salzmann, Ionescu-Somers, \& Steger, 2005). It is comprehendible and inevitable that research on CSR can boost the role of business in society. However, previous research shows that CSR is not taught as a formal course at most university level degrees, with limited interest in research in Pakistan (Yunis, 2009). Moreover, there is a sample of conferences where CSR is made a topic for panel sessions, but it is often observed that the focus of these presentations (labeled as CSR) tends to only contain examples of 
corporate philanthropy and the examples cited as CSR best practice often describe charitable acts by companies (SECP, 2005). In a situation where there is a lack of both theoretical and practical CSR knowledge and experience, this attitude invariably goes unchallenged.

More recently, Memon, Wei, Robson, and Khattak (2014) claim that CSR is still a newly establishing field which needs to be developed academically in the context of Pakistan. Results have demonstrated that there are no educational programs for CSR in higher educational institutes. Now and again the projects instigate a single module on ethics. Organizing ideas such as designing courses which impart moral knowledge was additionally noted, however the majority of the institutions did not offer CSR as a subject. A similar study analyzed the subject of CSR with respect to how the higher education institutions in Pakistan can address the obstacles prevailing in the academic field and enhance their execution in conferring the learning and practices of CSR to their students (Chaudhry, 2014). Academic issues were addressed from the point of view of instructing and preparing of CSR in Higher Education Institutions and their dependable impact on social and hierarchical life.

In order to scrutinize the systematic updated account of academic research of CSR in Pakistan, this paper attempts to review literature mainly from key white and published academic papers ${ }^{4}$ in the following sections.

\section{CSR: An Insight from Pakistan}

\subsection{Chronological Picture}

CSR research in Pakistan has been going on for more than a decade. Apparently, Ray (2000) work can be considered as first ever CSR related research in the context of Pakistan. This case study examines issues of child labor in Pakistan and Peru. Along with this, the research relates child labour with factors such as the replacement of child labour for adult labour and family income. A few important distinctions were also highlighted in this study concerning the child labour situation in Pakistan and Peru. For instance, In the Pakistan context, a positive relationship between child labour and family income was shown, however, a negative correlation was found between child schooling and poverty. On the other hand, in the data from Peru, both of these hypotheses were not proved. Concluding that in the case of Pakistan with the promotion of female education and infrastructure, child labour can be reduced

4 The purpose of reviewing key white and published papers is that they demonstrate authenticity, reliability, validity, and quality higher than that of non-published sources of researches (newspaper articles, WebPages and NGO reports). 
considerably.

Sustainable Development Policy Institute (SDPI, 2002, p.34) has published a report, which focuses on the phenomenon of natural disasters and CSR in the context of Pakistan. Findings of this reports suggests that business's social response was reactive rather than proactive in cases of natural disasters and only those businesses help the society in such scenarios that are in some way involved directly in the disaster in the first place. It was also noted that businesses get involved through public private partnerships in such cases. Another interesting finding of this study was that CSR has not been "internalized" in the businesses of Pakistan and that they are generally enforced upon them by some "external Factors". This report also suggests that short term CSR investments which help better the image of the business is preferred by the Multinational Companies (MNCs) such as landscaping, billboards and events of cultural nature. Companies which are doing substantial work in areas such as child labour, health, education and the environment and have pronounced CSR practices are Reebok and SAGA Sports also known as NIKE, Unilever Pakistan and The Engro group of industries.

Lund-Thomsen (2004) study proposes that corporate social and environmental responsibility (CSER) short comings are not only the fault of the management of the companies but rather they ought to be placed in local and international political and economic context and their mutual interaction. The research argues that "global value chain analysis" is an essential tool which should be used to comprehend the harm to the local environment and to the mental and physical health of the locals. A case study in Kasur (Pakistan) has been used as an example to link this conceptual critical framework to depict a conflict between the community and a company. This study also explored that even though on the surface a small number of companies considered themselves as being dedicated to CSR. However, in reality these are not willing to adjust their practices of polluting the environment. In conclusion, he added that more in-depth research on the understanding of CSR in a contextual approach is much needed.

Hussain-Khaliq (2004) examined issues of child labor in the football industry in Pakistan. A case study approach has been applied to understand the role of SAGA sports and international labour organization (ILO) in eliminating child labor from the football industry. This study captured issues like "value of export lead social consciousness" and "child labour". Moreover, further issues like the rights of the employees and social investment also has seen significant improvement. In conclusion the study states that the problem of child labour might have been stopped in this particular industry. However, they might have been moved to other local industries still employing child labour due to lack of awareness in other local industries inside Pakistan. 
The Securities and Exchange Commission of Pakistan (SECP), a government regulatory authority, presented a survey based report on CSR in 2005. According to this report companies in Pakistan are focused mainly on philanthropic work and legal compliance. Focus is limited on initial policy developmental stages of CSR. Companies' plans are short term and efforts are more situational and not a part of a continuous strategic process. CSR is not considered as a core value of corporations. Furthermore, MNCs and other large local companies with international associations are more susceptible and open to adopt and employ CSR practices. Environmental protection measures (such as responsible waste management, energy conservation, recycling and other sustainable practices) are also adopted by a small number of companies. Other important areas such as providing transport facilities to employees, corruption control and food subsidies are not being generally focused upon. It is interesting to note that unionization of employees and stakeholder engagement is discouraged. Additionally, the reporting of CSR activities is considered as a low priority for them. The suggestion that CSR policy should evolve via business and institutions like stakeholders' engagement was also made in this report.

The Pakistan Centre of Philanthropy (PCP) published a survey based research on philanthropic activities of the publically listed companies in Pakistan in 2005. According to this study, donations were the most popular mean through which most of the philanthropic activities were conducted. It can be concluded from this that the scope of the broader CSR has not been fully understood. Report reveals that $64 \%$ of all the publically listed companies are in some way involved in some social development endeavour. The major contribution to society from these companies is generally due to either faith based or due to humanitarian relations. Moreover, it was indicated by some of the companies that the major reasons for these charity based activities were factors such as marketing advantages, tax benefits and improved public image. A follow-up survey report was published by the PCP in 2006 to the 2005. A substantial increase in the activities of public limited companies of philanthropic nature was observed in the 2006 report as compared to the 2005 report. Even though corporate philanthropy has been seen to be on the rise, it has also been argued that it still suffers from the lack of proper organization and proper documentation, also is mostly health and education focused.

Janda and Wilson (2006) focus on CSR from a social investment perspective in Pakistan. The study suggests that local Pakistani firms should adopt the best CSR practices of MNCs and follow guidelines of socially responsible investment (SRI) funds. Consequently, local firm can increase their economic profit. In agreement with 2005 SECP report, this particular study also shows that MNCs are the first in taking the lead in CSR practices. In addition to this, it also claims that Pakistani based 
local firms are not active members of global impact and global reporting initiatives and suggest that more sophisticated CSR practices can be adopted in Pakistan, by becoming active members in these international bodies. Janda and Wilson (2006) are not in agreement with the SDPI (2002) and claim that stakeholder oriented CSR practices are operated on a broader scale by the MNCs in Pakistan.

Khan's (2006) study helps to understand the conflict between CSR and the competitiveness of a firm. This research examines 18 textiles manufacturing plants in Pakistan that export their products to the USA. No issues from the perspective of CSR regarding child labour were observed in the sample which was a major source of concern for the international community in the previous decade of the 90s. Substantial improvements in the sectors of health conditions and safety were also observed due to the new standards of compliance. In addition, factory owners opposed the argument that CSR brand is not properly operating in the local Pakistani context and is a merely imitating the "western norms" of CSR. Furthermore, the owners of these plants are more anxious about the CSR audits which are up to 22 in number. In conclusion, mandatory CSR regulation is not likely to happen in near future. However, the collaborative efforts amongst the NGO, public and private sectors are progressing.

Ahmad (2006) conducted a questionnaire based interview study concerning perceptions and practices of CSR in Pakistan. Vital CSR issues were explored in this non-randomly selected sample of set of 16 companies. The study captures different kinds of CSR activities observed in Pakistan and importance of different stakeholders. This study claims that there is significant divergence on the issue of CSR in Pakistan. Employees 'welfare and corporate philanthropy are the major focus of the CSR activities in majority of the companies. Ahmad (2006) also claims in the study that factors such as the size of the company and the overall financial performance of the company had restraining effect on obligations of social nature. Nevertheless, the first priority of most business unsurprisingly was a good financial performance. Additionally, this study is in agreement with the fact that western-style CSR is emerging but is still at its initial stages of development in Pakistan.

A fieldwork based case study was conducted by Khan (2007) in the Pakistani football manufacturing industry. The "representational practices" of international businesses involved in "social inequities" were the focus of this study. Four basic feasible options were proposed via a conceptual framework, which deal with the ethical issues faced by international businesses in the developing countries. According to Khan (2007) representational practices are very important for international businesses operating in the developing world. In the developing regions, the welfare of poor will suffer if stakeholders are not involved in their practices. Likewise, inaccurate 
representation can be a result, if those foreign bodies who wish to see ethical business practices prosper are not able to comprehend the complex nature of representation.

A viable contribution was made into the literature of the football industry in Sialkot, Pakistan by Lund-Thomsen (2013). A case study research was conducted which highlighted the issue of gender discrimination alongside the setback of prevailing child labor. This study examined the relationship between the vertical forces (the governance of Global Production Networks) and the horizontal forces (the local contextual environment of work). It was revealed that the football industry operating in Sialkot was highly gender biased because it inducted males into the labor forces and avoided hiring females.

Ali, Rehman, Yilmaz, Nazir, and Ali (2010) linked CSR with customer satisfaction, product service qualityand consumer purchase intention and its effect was examined on consumer loyalty. The study demonstrated a lack of significant relationship between consumer purchase intention and CSR activities in the cellular industry of Pakistan. The study suggests that these days' firms are building stakeholder relationships in order to seek competitive advantage over other firms. Similarly, another study was conducted to examine the impact of practicing CSR on the firm's image in the FMNCs by investigating the viewpoints of over a 100 students in Pakistan. The study revealed that there is a positive relationship between branding of CSR and a firm's brand image (Naqvi, Ishtiaq, Kanwal, Ali, \& Inderyas, 2013). One more study in the context of Pakistan revealed the relationship between tax avoidance and the fact whether a company practiced CSR activities. The results revealed that those companies which did not practice CSR avoided the obligation of tax payments. Moreover, the companies that did not practice CSR had an aggressive attitude towards the responsibility of paying taxes (Khan, Yousaf, Khan, \& Yasir, 2014)

Literature reveals that the potential impacts of Corporate Governance (CG) components on CSR disclosure were examined (Majeed, Aziz, \& Saleem, 2015). The yearly reports of organizations for the year 2007-2011 were inspected to investigate the relationship between CG and CSR reporting. The study considers the components of $\mathrm{CG}$, for example, board size, foreign nationalities, independent directors and female representation in the board, proprietorship focus, institutional ownership, firm size and productivity. The method of multiple regressions is utilized to quantify the effect of CG components on organizations' CSR reporting. The results of the study exhibit that general CSR reporting by Pakistani organizations are positive and noteworthy with respect to board size, fundamentals ownership, proprietorship focus and firm size on CSR reporting. The outcomes likewise show opposite connections between the female and explicit representation in the board and CSR reporting. This study recommends that organizations ought to review their CG exercises, identified 
with CSR, keeping in consideration the end goal to substantiate themselves as great corporate natives to all identifying stakeholders.

A novel study with respect to methodological stance was conducted for the first time in the context of Pakistan (Butt, 2016). A mixed study approach was used to determine how CSR is impacted by factors such as trust, purchase intention, awareness and religiosity. All the factors tend to positively influence CSR. However, religiosity did not impact consumer behaviour with respect to CSR in the context of Pakistan.

\subsection{Thematic Review}

A thematic evaluation of the CSR literature, reviewed in Pakistan, has been conducted in this section. A thematic review serves to remunerate critical perspectives on specific body of literature and identify gaps to suggest further issues related to a perspective (Ferragina \& Seeleib-Kaiser, 2011). In the following review, themes related to human resource management, marketing management, financial management and stakeholders' issues are discovered and discussed through reviewing CSR literature in Pakistan.

\subsubsection{The Stakeholders Engagement}

CSR is defined as organizations position and activities with reference to perceived stakeholders or at the least societal responsibilities (Brown \& Dacin, 1997). To understand the precise definition of CSR and its importance for the companies, one needs to understand their stakeholders' needs and ambitions while formulating their CSR strategies (Welford, 2005).Their involvement will show the organizations legitimacy and will also provide the organization with an opportunity to work in a balanced way between private and public benefits (Hess \& Warren, 2008). In order to sum it up, CSR is an idea that has to be placed in a relevant context. Literature review reveals that in Pakistan many NGOs (as stakeholders) are taking responsibility by working together with organizations on CSR issues. However, companies are yet to involve the stakeholders in their strategic processes related to CSR (Khan, 2006; SECP, 2005). This shows that in Pakistan, stakeholders are less important factor and have low institutional representation (Ahmad, 2006; Khan, 2007).

\subsubsection{CSR Financial Performance and the Financial Institutions of Pakistan}

Immense empirical contribution has been invested by researchers in the form of linking CSR with the governance of financial institutions and financial performance. CSR has been linked with Islamic Finance, CSR Reporting, and Disclosure in numerous forms in the context of Pakistan. For instance, Iqbal, Ahmad, Basheer, 
and Nadeem (2012) relate effect of CSR on Corporate Financial Performance (CFP) in Pakistan's corporate area. These partners incorporate shareholders, clients, and lenders. Second, size of the firm, figured as business sector capitalization, tends to change the outcome yet with negligible effect. Third, CSR to shareholders remains a steady element to impact the organization's execution both in KSE 100 record organizations and non KSE 100 list organizations. Moreover, CSR to clients is the most compelling variable on CFP if there should be an occurrence of KSE 100 record organizations while CSR to creditors is the most persuasive element in the event of non KSE 100 file organizations. Fifth, there is a negative effect on CFP of CSR to banks in the event of KSE 100 list organizations. Sixth, CSR to government, representatives, and dealers is yet to contribute towards monetary execution of organizations to the extent that budgetary indicators can be utilized as intermediaries of CSR. However, it has been revealed that there is a negative relationship between the stock ownership and corporate responsibilities assumed by employees in Pakistan (Ehsan, Kaleem, \& Jabeen, 2012).

The nature of relationship between a firm's financial performance and CSR of 'The Cement Sector Firms' recorded on KSE were investigated (Rehman, Baloch, $\&$ Sethi, 2015). Board information from 15 firms recorded on KSE for the time of 2006 to 2012 was gathered and examined by applying measurable instruments like correlation and generalized least square random effect regression. The exploration discovered positive relationship between the financial performance and CSR of the organizations concentrated on under this examination. Likewise, a positive relationship between CSR and financial performance of 15 enlisted KSE companies was demonstrated from the period of 2008 to 2014 (Kiran, Kakakhel, \& Shaheen, 2015). All in all, CSR is known to have a positive influence on the financial performance of companies in Pakistan (Qazi, Ahmed, Kashif, \& Qureshi, 2015). A significant domain of CSR is environmental in nature. Environmental Risk Management is an area which contains four dimensions: reactive, proactive, accommodative, and defensive. A study investigated common environment risk management methodologies and its association with task financing activities in the banks of Pakistan (Aslam \& Abdullah, 2015). To accomplish the study point, a questionnaire survey was designed to gather the information from banks by applying simple random sampling methods. In this exploratory study, regression analysis and cluster analysis were employed. Taking into account the exploration discoveries, most of the banks embrace the defensive and reactive procedures in Pakistan, because environmental criteria are of optional significance contrasted with budgetary and financial criteria. Hence the study demonstrated that banks operating in Pakistan need to enhance and actualize more proactive environmental risk techniques to improve the effectiveness in task financing choices. 


\subsubsection{CSR and Islamic Banking}

There have been numerous studies which highlight and clarify the idea and components of CSR. It has immeasurable applications in the field of ethics, marketing, accounting, management and numerous different territories including Corporate Finance. It has accomplished unique significance in the current age in the field of Corporate Finance. The target of CSR is to advance advantages from expansive organizations' operations to nearby groups. It guarantees that the private sector may not disregard the human rights and gives the advancement of the human rights. It likewise builds the straightforwardness in business practices and center work benchmarks. It states to identify within an organization, which administers itself, satisfies its main goal, lives by its qualities, connects with its stakeholders, measures its effects and reports on its exercises. The Shariah is an initial step for comprehension of CSR in Islam. The primary parts of Shariah clarify that corporate social responsibility and these segments are: faith (Aqidah), morality (Alkhliq), and fiqh (legal rulings). Taqwa (Allah's awareness) is an essential point of convergence to build up the relationship of man with Allah and towards the exercises of this world. Pakistan is focused on building up a socially and ecologically responsive corporate share and is assuming a proactive part in the improvement of CSR society in the nation's business field (Adeneye \& Ahmed, 2015).

Moreover, the effect of CSR among Islamic and Conventional Banking framework in association with earnings per share (EPS), return on asset (ROA), return on equity (ROE) were examined (Malik \& Nadeem, 2013). An investigation was led, in light of the yearly reports of 4 banks for the year 2010-2011. To examine the relationship between EPS, ROA, ROE and CSR models were employed. The outcomes demonstrated that there is absence of CSR in Pakistan and the relapse model demonstrated that there is a relationship between productivity (EPS, ROA, ROE) and CSR effects. The Financial foundations which actualize CSR in their operations achieve more benefit for the long haul time frames.

\subsubsection{CSR and Consumer Behavior in Pakistan}

CSR is a key issue and under open deliberation in the contemporary business world. In the developing nations, organizations need to confront genuine results with respect to the execution of CSR practices. Sarfraz (2014) investigated whether CSR has same part in telecom industry of Pakistan with respect to buyers' attitudes. A study included a questionnaire survey and targeted more than 160 customers of various telecom organizations in Pakistan. Information was gathered through verbal and non-verbal ways. Results demonstrated that in Pakistan telecom industry, corporate social obligation has no part in the maintenance of buyers. However, another 
quantitative study (Ali, 2011), which was conducted in the cellular industry of Pakistan demonstrated that CSR practices strengthen the reputation of a corporation and building strong purchase intentions in the developing country context.

Another study related to consumer behavior in the FMCG sector of Pakistan (Muzhar, Rashid, Rab Nawaz \& Qamar, 2013). The study revealed that Cause Related Marketing (which has its roots in CSR) had a positive impact on the purchase decision of consumers. However, it had a mediating effect on consumer attractiveness and corporate image of a firm. Likewise, another study revealed the effect of Cause Related Marketing, a domain that is used interchangeably with CSR, on the consumer attitudes (Sheikh \& Beise-Zee, 2011). It was concluded that CRM practices had a positive influence on developing positive attitudes of consumers towards a corporation.

A different approach of case study was employed by Pakistan Tobacco Company (PTC) to explore the consumer attitudes towards controversial products through the implementation of numerous CSR practices (Idrees \& Ullah, 2011). It was found that despite the commodity offered by PTC is a controversial one, as cigarette is a harmful product, yet consumers depicted positive impressions regarding PTC because of its CSR practices.

A similar study (Hameed, 2011) on Unilever Pakistan revealed that stakeholder dialogue is an immense challenge for the company as on one hand, the shareholders demand a significant amount of profit irrespective of the ecological factors that the company should consider. On the other hand, the consumers demand environmental friendly practices to be undertaken by the company.

\subsubsection{CSR and Entrepreneurship}

There is a limited research relating CSR with entrepreneurship. A study (Jan, Amin, Tariq, Haq, \& Ali, 2014) revealed self-satisfaction of the business entrepreneurs crosswise over Peshawar KP, Pakistan in connection to the CSR practices. The study highlighted the effect of three CSR dimensions to be specific environmental concerns, health concerns, and the literacy concerns. For this reason a questionnaire was employed. The paper revealed CSR practices are altogether identified with the self-satisfaction of the entrepreneurs crosswise over Peshawar KP, Pakistan.

\subsubsection{CSR and Organizational Behavior}

Regardless of the unfathomable and multidimensional research directed on the thought of CSR and its positive relationship with various outer variables, next to no center has been given to study its impact on the employees' state of mind and conduct which may impact their job proficiency, job adequacy, work quality and in this 
manner the general employment execution of people. For instance, a study (Ahmad, Shehzad, \& Zafar, 2014) intended to examine the impact of CSR recognition on the notion of Job Performance i.e. job productivity, work adequacy and occupation nature of employees with Overall Justice Perception as middle variable. Information was gathered in two unique ways through polls from three distinct associations in Telecom sector of Pakistan. An aggregate specimen size of 217 was recorded. Results were measured through relapse investigation and Preacher and Hayes (2008) large scale for intercession. The outcomes demonstrated a feeble however critical positive impact on Job effectiveness, Job quality and Overall Job Performance. The general equity discernment was additionally observed to be emphatically affected by CSR and also noteworthy positive part of general equity observation between CSR recognition and Job Performance was found.

After a long stretch of examination on this subject, results show that inspiring employees and retaining them is still a debilitating test for organization. Khan et al. (2014) investigated the effect of prizes and CSR on employees' motivation in Pakistan. This study particularly analyzed the relationship between inborn rewards, extraneous rewards, internal CSR, external CSR (customer related), external CSR (neighborhood groups related), external CSR (business partner related) and employee motivation. It additionally looked at relationship between employee motivation and authoritative duty. Representatives of Bahawalpur and Rahim Yar Khan were the specimen of this examination. Sample size of 150 respondents was utilized and information gathered through self-managed survey which was examined in SPSS 16 utilizing relapse method. The outcome portrayed that there is huge connection between extraneous rewards, external CSR (neighborhood groups), external CSR (business accomplice) and worker inspiration and there is likewise huge relationship between representative inspiration and hierarchical duty. Administration ought to concentrate on extrinsic rewards, outer CSR (neighborhood groups and business accomplice related) to rouse representatives for hierarchical responsibility.

A novel study (Hamid \& Zubair, 2016) endeavored to examine the relationship amongst CSR and organizational commitment among employees in the corporate sector. Results demonstrated that CSR and organizational commitment were absolutely corresponding with each other among employees in the corporate division. However employees with amplified job tenure and working at senior employment positions indicated more good view of CSR and larger amount of organizational commitment.

\section{Brief Debate on Key Findings from the Literature}

\subsection{CSR Conception}

The four important characteristics of a good corporate citizen as suggested by Carroll (1998) include economic responsibility, compliance with legal responsibility, 
engagement in ethical behaviour and philanthropy. These four dimensions do not exist in isolation and each dimension is an important element of good corporate citizen. The terms CSR and corporate philanthropy are used interchangeably in the Pakistani context. According to most literature with the exception of MNCs, companies consider CSR activities as a short term activity of charity or philanthropic nature rather than an on-going process (Ahmad, 2006; Janda \& Wilson, 2006; SDPI 2002; SECP 2005). In addition, no clear evidence of Carroll's model (1998) is present regarding economic, legal and ethical perspective in the literature.

However, the trends have been changing over the past years. Safi and Ramay (2013) examined the effect of CSR on Consumer Behavior in Pakistan. The study dissected whether shoppers figure organization's CSR activity before purchasing choices of products in the context of Pakistan. In addition, conception of CSR given by Carroll (1991) was implemented here that locates entire scope of economic, legal, ethical, and philanthropic duties. A survey questionnaire was designed and 313 responses were gathered over the diverse corners of Pakistan that further prompted uniqueness of the findings. The investigation demonstrated that there is a positive relationship between all four domains of CSR initiatives and consumer responses. In any case, Pakistani buyers' need seemed, by all accounts, to be not quite the same as offered via Carroll's Classical Pyramid, where economic duty was thought to be the best need, followed by philanthropic, legal, and ethical obligations. Similarly, a study (Saeed, Lodhi, \& Afzal, 2013) was conducted to demonstrate brand equity in the banking sector of Pakistan. The purpose behind the study was to contextualize CSR in Pakistan. The respondents brought about the welfare activities, for example, giving assets, building schools and streets, setting up eye camps in provincial groups and arrangement of counterfeit arrangements for deprived individuals. It was understood that the idea of CSR is at preparatory stage in Pakistan. The huge number of organizations are endeavoring to comprehend and in process to be mindful of this impression. A large portion of firms have commitments to philanthropy, group advancement, and charity for helpful or religious purpose. In any case, the idea of CSR is not organized by a significant number of organizations, operational in Pakistan. Generally, the idea of CSR is associated with charity.

\subsection{Non-Contextual}

In many countries and cultures MCN's are working as global citizens because every country and culture is unique in its own, therefore, it is important for organizations to discern the local meaning of the term CSR. According to literature it seems important that the managers from different countries especially western countries should understand the contrast between behavior and ethics (Jackson \& Artola, 
1997). It is important to understand the differences (due to cultural environment) between the operating conditions of west and south (Ramasamy \& Ting, 2004). In spite of that, in Pakistan literature suggests that MCNs (from the west) are practicing western sort of CSR and it is not relevant to Pakistani context (Ahmad, 2006; Khan, 2006; Lund-Thomsen, 2004; SECP, 2005).

\subsection{Leader in CSR Practices}

MCNs (both foreign and locally originated) in the case of Pakistan seem to be proven leaders in pioneering activities of CSR (Ahmad, 2006; Khan, 2006; Lund-Thomsen, 2004; SECP 2005). Literature (Adams \& Hardwick, 1998; Goodstein, 1994; Powell $\&$ DiMaggio, 1991) proves that for CSR practices, the size of the organization is the key determinant; hence MCNs should keep practicing CSR in this region (Pakistan).

\subsection{Situational and Short Term}

In Pakistan critical happenings are sometimes considered unintended factors for CSR initiatives because they have a long term positive impact on society. The organizations sometimes show more interest towards CSR activities and in return use it as catalyst to reduce pressures (Greening \& Gray, 1994; Hess \& Warren, 2008; King \& Lenox, 2000) like SDPI (2002) report shows that organizations' (in Pakistan) CSR activities seem situational. Yet in Pakistan it has been found that business activities are occasion situated and not a piece of long haul vital procedure (Ahmad, 2006; SDPI, 2002).

\subsection{Role of Pressure Groups}

Businesses may face "boycotts" and "negative publicity" from many pressure groups as a result of irresponsible behavior (Hess \& Warren, 2008). International business community boycotted the buying of football from Pakistan in the mid-90s when few pressure groups such as NGOs and international media raised the issue of child labor in Pakistani football industries (Winstanley, Clark, \& Leeson, 2002). This resulted in the elimination of child labor and improved working conditions in all companies that were export oriented (Khan, 2007; Khan, 2006; Ray, 2000).

\subsection{CSR Strategy in Pakistan: Political, Economic, or Organizational Legitimacy}

An outline on the concepts of OL (Organizational Legitimacy) and PE (Political Economy) put forward by Woodward, Edwards, and Birki (2001) argues that these as two different dimensions of corporate social behaviour. In addition to this, it also communicates that businesses operate under a directive from society, but which can 
be withdrawn if organizations seem not to be doing the things society expects from them". So to justify their existence in society businesses are compelled to take some action in CSR activities. Another suggestion made is that PE is an alternative approach which is reactive approach that business takes to influence society. It has been argued in the literature that in order to understand the CSR strategies of companies in the context of Pakistan, in the framework proposed by (Woodward et al., 2001). Those reactive strategies have been practiced by the companies of Pakistan rather than making them a part of the company's core value and strategy (Ahmad, 2006; SDPI, 2002; SECP, 2005). We can conclude from this that most of the businesses responsible are to provide legitimacy in the society in which they operate in by meeting the expectations of the society.

\section{Theoretical Contributions}

Whilst demonstrating the nature of labor agencies operating in the football industry of Sialkot, Pakistan, Lund-Thomsen, Nadvi, Chan, Khara, and Xue (2012) contributed to the framework by adding the concept of labor agency through the perspective of resilience in order to explore how the labor forces experience to thrive in a challenging environment like Pakistan. Moreover, Ayub, Iftekhar, Aslam, and Razzaq (2013) contributed to the model of Mozes, Josman, and Yaniv (2011) by mediating the role of behavior and training in order to understand the effect of employee participation in CSR activities to its identification with the corporation. The empirical results revealed that such trainings created dissonance in the behavior of employees. However, it revealed positive results such as employee motivation and establishing a good image of the corporation.

Another study contributed to both the framework of CSED and empirical evidence on CSED in the developing nations (Ali \& Rizwan, 2013). The researcher argued that institutional theory is more refined theory than different theories. The researcher argued that organizations are exposed to external pressures which burden the firm to embrace specific practice (i.e. CSED) in the institutional setting. Increasingly the power of institutional forces, more rapidly of the specific practice (i.e. CSED) should be embraced by the firm to appear like different firms working in the institutional environment.

In the context of Islamic literature devised and progressed in the field of management, for instance, Darus, Yusoff, and Azhari (2013) categorized CSR as an Islamic CSR in order to provide the practitioners with a theoretical guide to practice CSR in an Islamic fashion. Although the study encompassed the Middle East nations as a whole, contextual and empirical data of Pakistan was a significant part of the study. 
Since little consideration has been given to CSR in the field of entrepreneurship in Pakistan (Zafar \& Farooq, 2014) contributed to the theory of entrepreneurship by stating that when small firms practice CSR in Pakistan, they can produce results such as trust, motivation, reputation, and attraction of better employees towards the entrepreneurial firm.

\section{Conclusion and Future Research Agenda}

Different scholars have noticed that western business is ahead of Asian business in many aspects of CSR (Ang, 2000; Dirany, Jamali, \& Ashleigh, 2009; Low, 2004; Welford, 2004; Westwood \& Posner, 1997). Drawing upon the above review of literature, evidence reveals that particularly in Pakistan, CSR level is much below than average found in Europe, America, Africa and Asia (Salzmann, Ionescu-Somers, \& Steger, 2005). However, this review of literature indicates that there is considerable improvement in few CSR issues such as child labour, health and safety in textile and leather industry in Pakistan (Khan, 2007; Khan, 2006; Ray, 1999). In term of numbers, academic research is limited but growing. However, methodological and theoretical scope is still limited. It is interesting to note that in last ten years, two factors i.e. pressure groups (Media, NGOs etc.) and research (academic and non-academic) has targeted child labour in leather and textile industry.

Figure 1 is created based on CSR review of literature in Pakistan. Perhaps, an argument can be generated through Figure 1. If research and pressure groups focus on any specific societal issue or a particular business sector, as a result businesses will act responsibly and conflicting CSR issues will be resolved (i.e. child labour issue will

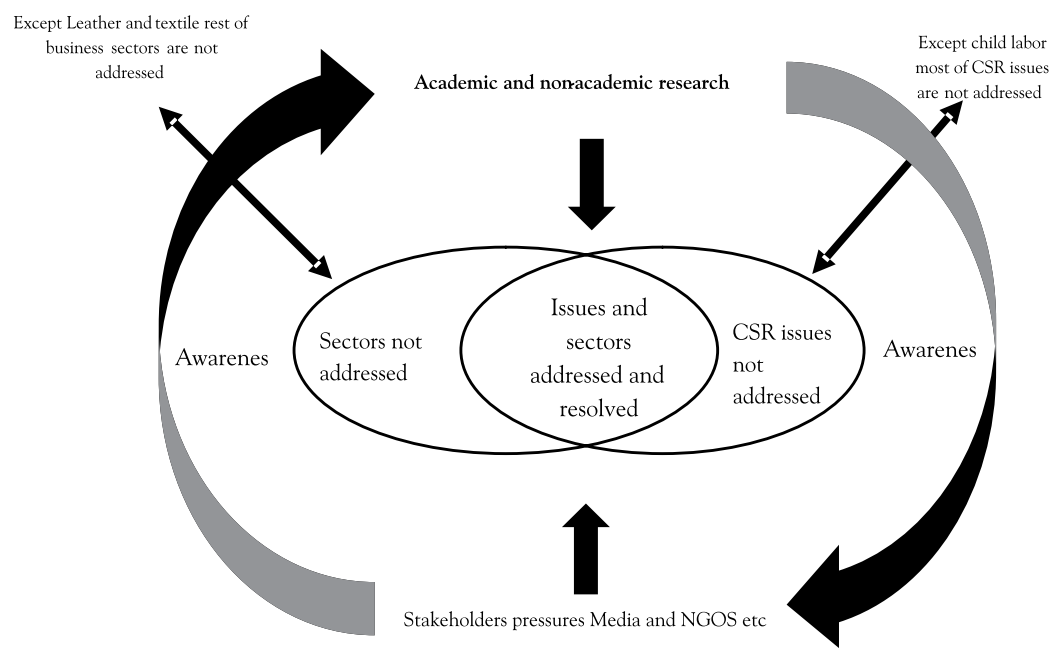

Figure 1: CSR issues in Pakistan 
be completely abolished from the textile and leather industry in Pakistan).

This figure also suggests that different CSR environmental and social factors are yet to be explored, investigated, and examined in Pakistan. To address these issues, it is suggested that the future research should cover more CSR dimensions, such as It is obvious from the review of literature that businesses especially MNCs exercise Western style CSR practices and lack local contextual understanding (Ahmad, 2006; Khan, 2006; Lund-Thomsen, 2004; SECP, 2005). Therefore, CSR issues such as cross-cultural implications of CSR and CSR in local context (Imbun, 2006; Jamali, 2006; Min Foo, 2007; Muller, 2006) might be useful to investigate. In addition, Institutional theory could be used to understand the localised aspect of CSR.

- Previous researches (for instance Memon et al., 2014: SECP, 2005) claim that there is a limited role of academia and research in promotion of CSR in Pakistan. Therefore, it is suggested to explore the state of current curricula and academia and understand the role of these normative institutions in promotion of CSR in the context of Pakistan.

- Environmental issues such as air and water pollution, industrial waste management, energy conservation etc. (Hussain, 1999; Menguc \& Ozanne, 2005; Roarty, 1997) and green business is still to be addressed as these have not been examined from CSR perspective in Pakistan.

- SECP (2005) and Ahmad (2006) claims that there is no stakeholder engagement in business. Moreover, there is not a single study which focuses on this issue in Pakistan. Stakeholder's management issues like Stakeholder's identification and mapping, stakeholder's engagement and conflict management (Abma, 2000; Donaldson \& Preston, 1995) research topics are proposed for future research.

- SECP (2005) indicated low level of corporate social reporting in Pakistan. Perhaps, there is no single study on corporate social disclosure (CSD). Existing issues include identification and examination of reporting, medium of reporting, key variables reported and ignored in reporting processes, accountability, credibility and audit etc. (Belal, 2001; Gray, Kouhy, \& Lavers, 1995; Tsang, 1998). This study might be interesting on the basis of its antithetical result. The myth of CSR being an emerging phenomenon is disproved here on the basis of quite a few studies conducted in research. Few exploratory and case study researches are on the scene. In addition, it is observed that very little academic research is available on CSR in Pakistan. Scientific, pragmatic, and empirical approach is missing in both academic and non-academic research which is the factor causing lack of rigour in research. The companies practising CSR are involved in short 
term, reactive, charity based activities. Moreover, they are practising it without involving stakeholders. Only NGOs have started to initiate in terms of research and engagement with business.

\section{References}

Abma, T. A. (2000). Stakeholder conflict: A case study. Evaluation and Program Planning, 23(2), 199- 210.

Adams, M., \& Hardwick, P. (1998). An Analysis of corporate donations: United Kingdom evidence. Journal of Management Studies, 35(5), 641-654.

Ahmad, I., Shehzad, K., \& Zafar, M. (2014). Impact of CSR perception on dimensions of job performance with mediating effect of overall justice perception. European Journal of Business and Management, 6(20), 94-108.

Ahmad, S. (2006). From principles to practice. Journal of Corporate Citizenship, 24, 115-129.

Adeneye, Y., \& Ahmed, M. (2015). Corporate social responsibility and company performance. Journal of Business Studies Quarterly, 7(1), 151-166.

Ali, I. (2011). Influence of corporate social responsibility on development of corporate reputation and customer purchase intentions. Romanian Review of Social Sciences, 1(1), 19-27.

Ali, I., Rehman, K., Yilmaz, A., Nazir, S., \& Ali, J. (2010). Effects of corporate social responsibility on consumer retention in the cellular industry of Pakistan. African Journal of Business Management, 4(4), 475-485.

Ali, W., \& Rizwan, M. (2013). Factors influencing corporate social and environmental disclosure (CSED) practices in the developing countries: An institutional theoretical perspective. International Journal of Asian Social Science, 3(3), 590-609.

Ang, S. (2000). The power of money: A cross-cultural analysis of business-related beliefs. Journal of World Business, 35(1), 43-60.

Aslam, M., \& Abdullah, I. (2015). Corporate social responsibility and natural environmental risk management strategies. International Journal of Social Sciences and Management Studies, 2(3), 21-27.

Ayub, A., Iftekhar, H., Aslam, M., \& Razzaq, A. (2013). A conceptual framework on examining the influence of behavioral training \& development on CSR: An employees' perspective approach. European Journal of Business and Social Sciences, 2(1), 33-42.

Awan, A. W., Kamal, Y., Rafique, M., \& Khan, S. (2012). Corporate social responsibility in Pakistan economy. Business $\mathcal{E}$ Economic Review, 4(1), 1-22.

Belal, R. (2001). A study of corporate social disclosure in Bangladesh. Managerial Auditing Journal, 16(5), 274-289.

Blowfield, M., \& Frynas, J. (2005). Editorial setting new agendas: Critical perspectives on corporate 
social responsibility in the developing world. International Affairs, 81(3), 499-513.

Brown, T., \& Dacin, P. (1997). The company and the product: corporate associations and consumer product responses. Journal of Marketing, 61(1), 68-84.

Butt, I. (2016). Corporate social responsibility and consumer buying behavior in emerging market: A mixed method study. International Journal of Business and Management, 11(7), 211-222.

Carroll, A. (1991). The pyramid of corporate social responsibility: Toward the moral management of organizational stakeholders. Business Horizons, 34(4), 39-48.

Carroll, A. (1998). The four faces of corporate citizenship. Business and Society Review, 100-101(1), 1-7.

Carroll, A. (1999). Corporate Social Responsibility: Evolution of a definitional construct. Business and Society, 38(3), 268-295.

Chaudhry, S. (2014). Impact of the CSR curricula in higher education institutions for producing socially responsible graduates. In International Conference on Postgraduate Research (pp. 368-382). Kuala Lumpur, Malaysia: ICPR.

Darus, F., Yusoff, H., \& Azhari, M. N. (2013). Environmental disclosure of islamic financial institutions ( IFIs ): Preliminary evidence from Malaysia. Journal of Energy Technologies and Policy, 3(11), 433-439.

Dirany, A., Jamali, D., \& Ashleigh, M. (2009). CSR is knocking: A call for HR to join. Business $\mathcal{E}$ Economic Review, 1(1), 8-14.

Donaldson, T., \& Preston, L. E. (1995). The stakeholder theory of the corporation: Concepts, evidence, and implications. Academy of Management Review, 20(1), 65-91.

Ehsan, S., Kaleem, D., \& Jabeen, S. (2012). Exploring the interaction between financial performance and corporatesSocial responsibility in Pakistani firms. Journal of Basic and Applied Scientific Research, 2(10), 10431-10439.

Ferragina, E. \& Seeleib-Kaiser, M. (2011). Thematic review: Welfare regime debate: past, present, futures? Policy and Politics, 39(4), 583-611.

Geva, A. (2008). Three models ofcCorporate social responsibility: Interrelationships between theory, research, and practice. Business and Society Review, 113(1), 1-41.

Gray, R., Kouhy, R., \& Lavers, S. (1995). Constructing a research database of social and environmental reporting by UK companies. Accounting, Auditing and Accountability Journal, 8(2), 78-101.

Greening, D. W., \& Gray, B. (1994). Testing a model of organizational response to social and political issues. Academy of Management journal, 37(3), 467-498.

Goodstein, J. (1994). Institutional pressures and strategic responsiveness: employer involvement in work-family issues. Academy of Management Journal, 37(2), 350-382. Hameed, Y. (2011). CSR implementation and concept at Unilever Pakistan (Master's thesis) .Karlstad Business School. Karachi, Pakistan 
Hamid, M. \& Zubair, A. (2016). Corporate Social Responsibility and organizational commitment among employees in the corporate sector. Pakistan Business Review, 7(4), 933-949.

Hess, D. \& Warren, D. (2008). The Meaning and Meaningfulness of Corporate Social Initiatives. Business and Society Review, 113(2), 163-197.

Hussain-Khaliq, S. (2004). Eliminating Child Labour from the Sialkot Soccer Ball Industry. Journal of Corporate Citizenship, 2004(13), 101-107.

Hussain, S. (1999). The ethics of 'going green': the corporate social responsibility debate. Business Strategy and The Environment, 8(4), 203-210.

Idrees, G. A., \& Ullah, I. (2011). CSR practices of a company toward sta.keholders: The case of Pakistan Tobacco Company (Master Thesis). Karisted Business School, Karachi, Pakistan.

Imbun, B. (2006). Cannot manage without the significant other: Mining, Corporate Social Responsibility and local communities in Papua New Guinea. Journal of Business Ethics, 73(2), 177-192.

Iqbal, N., Ahmad, N., Basheer, N., \& Nadeem, M. (2012). Impact of corporate social responsibility on financial performance of corporations: Evidence from Pakistan. International Journal of Learning and Development, 2(6), 107-118.

Jackson, T., \& Artola, M. (1997). Ethical belief and management behavior: A cross-cultural comparison. Journal of Business Ethics, 16(11), 1163-1173.

Jamali, D. (2006). Insights into triple bottom line integration from a learning organization perspective. Business Process Management Journal, 12(6), 809-821.

Jamali, D., \& Karam, C. (2016). Corporate social responsibility in developing countries as an emerging field of study. International Journal of Management Reviews.

Jamali, D., \& Neville, B. (2011). Convergence versus divergence of CSR in developing countries: An embedded multi-layered institutional lens. Journal of Business Ethics, 102(4), 599-621.

Janda, R. \& Wilson, J. (2006). CSR, contracting and socially responsible investment: Opportunities for Pakistani firms. CMER Working Paper No. 06-52, Lahore. Pakistan.

Jan, D., Amin, K., Tariq, D., Haq, D., \& Ali, D. (2014).Self Satisfaction of the entrepreneurs in relation to the CSR practices across Peshawar KPK Pakistan. Life Science Journal, 11(5), 36-40.

Kell, G. (2016). Everyone benefits from a better world: The role of business in society (1st ed., pp. 4-5). UN: United Nations Global Compact International Yearbook.

Khan, A. (2006). Pakistan Predicament: Corporate social responsibility in action. Policy Matter, 3(2), 5-9.

Khan, M., Yousaf, Z., Khan, Z., \& Yasir, M. (2014). Analysis of the relationship between CSR and tax avoidance: An evidence from Pakistan. The International Journal of Business and Management, 2(7), 53.

Khan, A. (2007). Representing children (1st Ed.). Karachi: Oxford University Press. 
King, A. A., \& Lenox, M. J. (2000). Industry self-regulation without sanctions: The chemical industry's responsible care program. Academy of management journal, 43(4), 698-716.

Kiran, S., Kakakhel, S., \& Shaheen, F. (2015). Corporate social responsibility and firm profitability: A case of oil and gas sector of Pakistan. City University Research Journal 5 (1) (110-119).

Kratou, H. \& Goaied, M. (2016). How can globalization affect income distribution? Evidence from developing countries. The International Trade Journal, 30(2), 132-158.

Low, C. (2004). A road map for corporate governance in East Asia. North western Journal of International Law and Business, 25(1), 165-203.

Lund-Thomsen, P. (2013). Labor agency in the football manufacturing industry of Sialkot, Pakistan. Geo forum, Retrieved from 44, 71-81.

Lund-Thomsen, P. (2004). Towards a critical framework on corporate social and environmental responsibility in the South: The case of Pakistan. Development, 47(S3), 106-113.

Lund-Thomsen, P., Nadvi, K., Chan, A., Khara, N., \& Xue, H. (2012). Labour in global value chains: Work conditions in football manufacturing in China, India and Pakistan. Development and Change, 43(6), 1211-1237.

Lund-Thomsen, P., Lindgreen, A., \& Vanhamme, J. (2014). Industrial clusters and corporate social responsibility in developing countries: What we know, what we do not know, and what we need to know. Journal of Business Ethics, 133(1), 9-24.

Majeed, S., Aziz, T., \& Saleem, S. (2015). The effect of corporate governance elements on corporate social responsibility (CSR) disclosure: An empirical evidence from listed companies at KSE Pakistan. International Journal of Financial Studies, 3(4), 530-556.

Matten, D. \& Crane, A. (2005). Corporate citizenship: toward an extended theoretical conceptualization. Academy of Management Review, 30(1), 166-179.

Malik, M. S., \& Nadeem, M. (2014). Impact of corporate social responsibility on the financial performance of banks in Pakistan. International Letters of Social and Humanistic Sciences, 10(1), 9-19.

Memon, Z., Wei, Y., Robson, M., \& Khattak, M. (2014). Keeping track of 'corporate social responsibility' as a business and management discipline: case of Pakistan. Journal of Cleaner Production, 74, 27-34.

Menguc, B., \& Ozanne, L. (2005). Challenges of the "green imperative": A natural resource-based approach to the environmental orientation-business performance relationship. Journal of Business Research, 58(4), 430-438.

Min Foo, L. (2007). Stakeholder engagement in emerging economies: Considering the strategic benefits of stakeholder management in a cross-cultural and geopolitical context. Corporate Governance: The International Journal of Business in Society, 7(4), 379-387.

Mozes, M., Josman, Z., \& Yaniv, E. (2011). Corporate social responsibility organizational identification 
and motivation. Social Responsibility Journal, 7(2), 310-325.

Muller, A. (2006). Global versus local CSR strategies. European Management Journal, 24(2-3), 189-198.

Muzhar, J., Rashid, S., Rab Nawaz, L., \& Qamar Uz Zaman, M. (2013). The relationship between corporate social responsibility and firm financial performance: A Case of Pakistan. Journal of Basic and Applied, 3(11), 34-45.

Naqvi, S. R., Ishtiaq, M., Kanwal, N., Ali, M., \& Inderyas, S. (2013). Impact of Corporate Social responsibility on Brand image in Different FMCGs of Pakistan. Interdisciplinary journal of contemporary research in business, 5(1), 79-93.

Pakistan Centre of Philanthropy. (2005). Corporate philanthropy in Pakistan: Survey of Public Listed Companies. Islamabad, Pakistan

Preacher, K. J., \& Hayes, A. F. (2008). Asymptotic and resembling strategies for assessing and comparing indirect effects in multiple mediator models. Behavior Research Methods, 40(3), 879-891.

Powell, W., \& DiMaggio, P. (1991). The new institutionalism in organizational analysis (1st ed., pp. 183-203). Chicago: University of Chicago Press.

Qazi, S., Ahmed, M., Kashif, S., \& Qureshi, Z. (2015). Company's financial performance and CSR: Pakistan context. Global Advanced Research Journal of Management and Business Studies, 4(5), 196-202.

Ramasamy, B., \& Woan Ting, H. (2004). A comparative analysis of corporate social responsibility Awareness. Journal of Corporate Citizenship, 2004(13), 109-123

Ray, R. (2000). Child Labor, Child Schooling, and Their Interaction with Adult Labor: empirical evidence for Peru and Pakistan. The World Bank Economic Review, 14(2), 347-367.

Rehman, A., Baloch, Q., \& Sethi, S. (2015). Understanding the relationship between firm's corporate social responsibility and financial performance: Empirical analysis. Abasyn Journal of Social Sciences, 8(1), 98-107.

Rischard, J. (2002). Global issues networks: Desperate times deserve innovative measures. The Washington Quarterly, 26(1), 17-33.

Roarty, M. (1997). Greening business in a market economy. European Business Review, 97(5), 244-254.

Saeed, R., Lodhi, R., \& Afzal, N. (2013). Impact of customer satisfaction and demographic factors on customer's loyalty in banking sector of Pakistan. Middle-East Journal of Scientific Research, 18(10), 1429-1435.

Safi, A. \& Ramay, M. (2013). Corporate social responsibility and consumer behavior: A study from Pakistan. Information Management and Business Review, 5(4), 194-202.

Salzmann, O., Ionescu-somers, A., \& Steger, U. (2005). The business case for corporate sustainability. European Management Journal, 23(1), 27-36. 
Sarfraz, M. (2014). Do consumers consider CSR, A case of cellular companies in Pakistan? Global Journal of Management and Business Research: A Administration and Management, 14(6), 30-34.

Schrecker, T. (2014). Globalization, austerity and health equity politics: taming the inequality machine, and why it matters. Critical Public Health, 26(1), 4-13.

Scherer, A. \& Palazzo, G. (2011). The new political role of business in a globalized world: A review of a new perspective on CSR and its implications for the firm, governance, and democracy. Journal of Management Studies, 48(4), 899-931.

Securities and Exchange Commission of Pakistan. (2005). Evaluation of the state of corporate social responsibility in Pakistan and a strategy for implementation, Islamabad. Pakistan.

Sheikh, S. U. R., \& Beise-Zee, R. (2011). Corporate social responsibility or cause-related marketing? The role of cause specificity of CSR. Journal of Consumer Marketing, 28(1), 27-39.

Sustainable Development Policy Institute. (2002). Corporate social responsibility and natural disaster reduction in Pakistan. Pakistan.

Tsang, E. (1998). A longitudinal study of corporate social reporting in Singapore. Accounting, Auditing and Accountability Journal, 11(5), 624-635.

Welford, R. (2004). Corporate social responsibility in Europe and Asia. Journal of Corporate Citizenship, 2004(13), 31-47.

Welford, R. (2005). Corporate social responsibility in Europe, North America and Asia. Journal of Corporate Citizenship, 2005(17), 33-52.

Westwood, R., \& Posner, B. (1997). Managerial values across cultures: Australia, Hong Kong, and the United States. Asia Pacific Journal of Management, 14(1), 31-66.

Winstanley, D., Clark, J., \& Leeson, H. (2002). Approaches to child labor in the supply chain. Business Ethics: A European Review, 11(3), 210-223.

Woodward, D., Edwards, P., \& Birkin, F. (2001). Some evidence on executives' views of corporate social responsibility. The British Accounting Review, 33(3), 357-397.

Yunis, M. S. (2009). CSR research "Back Home": A critical review of literature and future research options in Pakistan. Business $\mathcal{E}$ Economic Review, 1(1), 1-7

Zadek, S. (2001). Third generation corporate citizenship (1st ed.). London: Foreign Policy Centre.

Zafar, F., \& Farooq, M. (2014). Corporate social responsibility in small and medium enterprises to achieve organizational benefits. International Journal of Scientific and Engineering Research, 5(1), 2276-2283. 
